Published as: Anal Biochem. 2008 February 15; 373(2): 296-306.

\title{
A universal competitive fluorescence polarization activity assay for S-adenosylmethionine utilizing methyltransferases
}

\author{
Tiffany L. Graves ${ }^{a}$, Yi Zhang ${ }^{b}$, and John E. Scott ${ }^{a},{ }^{*}$ \\ aDepartment of Pharmaceutical Sciences, Biomanufacturing Research Institute and Technology \\ Enterprise, North Carolina Central University, Durham, NC 27707, USA \\ bDepartment of Biochemistry and Biophysics, Lineberger Comprehensive Cancer Center, \\ University of North Carolina at Chapel Hill, Chapel Hill, NC 27599, USA
}

\section{Abstract}

\begin{abstract}
A high-throughput, competitive fluorescence polarization immunoassay has been developed for the detection of methyltransferase activity. The assay was designed to detect $S$ adenosylhomocysteine (AdoHcy), a product of all $S$-adenosylmethionine (AdoMet)-utilizing methyltransferase reactions. We employed commercially available anti-AdoHcy antibody and fluorescein-AdoHcy conjugate tracer to measure AdoHcy generated as a result of methyltransferase activity. AdoHcy competes with tracer in the antibody/tracer complex. The release of tracer results in a decrease in fluorescence polarization. Under optimized conditions, AdoHcy and AdoMet titrations demonstrated that the antibody had more than a 150-fold preference for binding AdoHcy relative to AdoMet. Mock methyltransferase reactions using both AdoHcy and AdoMet indicated that the assay tolerated 1 to $3 \mu \mathrm{M}$ AdoMet. The limit of detection was approximately $5 \mathrm{nM}(0.15 \mathrm{pmol})$ AdoHcy in the presence of $3 \mu \mathrm{M}$ AdoMet. To validate the assay's ability to quantitate methyltransferase activity, the methyltransferase catechol- $O$ methyltransferase (COMT) and a known selective inhibitor of COMT activity were used in proofof-principle experiments. A time- and enzyme concentration-dependent decrease in fluorescence polarization was observed in the COMT assay that was developed. The $\mathrm{IC}_{50}$ value obtained using a selective COMT inhibitor was consistent with previously published data. Thus, this sensitive and homogeneous assay is amenable for screening compounds for inhibitors of methyltransferase activity.
\end{abstract}

\section{Keywords}

Fluorescence polarization; Methyltransferase; $S$-Adenosylhomocysteine; $S$-Adenosylmethionine; Catechol- $O$-methyltransferase

Methyltransferases are a diverse class of enzymes that catalyze the transfer of a single methyl group from a methyl donor molecule to a methyl acceptor. The vast majority use $S$ adenosylmethionine (AdoMet) ${ }^{1}$ as the methyl donor $[1,2]$. AdoMet is the second most

(C) 2007 Elsevier Inc. All rights reserved.

*Corresponding author. Fax: +1 919530 6600. jscott@ nccu.edu (J.E. Scott). 
widely used substrate molecule in the cell after ATP. Methylation is an essential and highly choreographed regulatory metabolic process. Small organic molecules and peptides and most types of cellular macromolecules, including DNA, RNA, protein, and lipids, can serve as substrates for methylation (for detailed reviews, see Refs. [2-7]).

A rapidly growing area of methyltransferase research focuses on methylation of histone tails by histone methyltransferases (HMTs) (for reviews, see Refs. [8,9]). Histone methylation is an epigenetic modification that has a role in formation of heterochromatin, $\mathrm{X}$ chromosome inactivation, and modification of gene expression patterns. Histone methylation occurs on arginine and lysine residues and is catalyzed by methyltransferases belonging to three distinct families of proteins: the protein arginine $N$-methyltransferase 1 (PRMT1) family, the SET-domain-containing protein family, and the non-SET-domain proteins DOT1/DOT1L. This histone methylation alters chromatin structure and, thus, regulates gene transcription. The methylation sites on histone proteins can serve as docking sites for different effector proteins that can mediate either activation or repression of gene transcription. Another process by which epigenetic modifications directly effect gene expression and chromatin organization is methylation of DNA at cytosine residues by DNA methyltransferases (DNMTs) (for reviews, see Refs. [5,10]). Several reports have detailed how deregulation of methylation can be the direct cause or result of cellular dysfunction. For example, in certain cancers, hyper- and hypomethylation of specific regions of DNA by DNMTs and rearrangement of chromatin due to HMTs are observed routinely and serve to silence and activate genes related to cell growth and malignancy [11-16].

The study of methyltransferase activity and its regulation continues to be an important and promising area of research in fields from oncology to neurology. Thus, there currently is a demand for the ability to screen large compound libraries to identify and optimize small molecules that modulate methyltransferase activity. Published methods for determining methyltransferase activity are not optimal for high-throughput screening; they are nonhomogeneous, are labor intensive, require large volumes, and/or are not very sensitive. In most currently used methyltransferase assays, the substrate to be methylated is fluorescently labeled or radiolabeled and the reaction products must be separated from substrate using chromatographic or extraction techniques. There have been reports of homogeneous methyltransferase assays [17-19]; however, they are not considered sensitive, involve the use of several enzymes, and/or require large volumes. Two recent reports detailed methyltransferase assays suited for high-throughput screening [20,21]. The assay by Woo and co-workers is an enzyme-linked immunosorbent assay (ELISA)-based restriction protection technique specific for DNA methyltransferases [21]. In that work, they were able to adapt their assay for low volumes for use in microtiter plates. However, the assay is nonhomogeneous, requiring several wash and incubation steps. The assay by Kurkela and coworkers is comparable to HPLC methods in sensitivity, but was optimized for a 96-well

\footnotetext{
${ }_{1}$ Abbreviations used: AdoMet, $S$-adenosylmethionine; HMT, histone methyltransferase; PRMT1, protein arginine $N$-methyltransferase 1; DNMT, DNA methyltransferase; ELISA, enzyme-linked immunosorbent assay; COMT, catechol- $O$-methyltransferase; FP, fluorescence polarization; mP, millipolarization; FPIA, fluorescence polarization immunoassay; AdoHcy, $S$-adenosylhomocysteine; BGG, bovine $\gamma$-globulin; DTT, dithiothreitol; DBA, dihydroxybenzoic acid; Ro 41-0960, 2'-fluoro-3,4-dihydroxy-5nitrobenzophenone; PMSF, phenylmethanesulfonyl fluoride; FITC, fluorescein isothiocyanate; DMSO, dimethyl sulfoxide; L-DOPA, 3-(3,4-dihydroxyphenyl)-L-alanine; RFU, relative fluorescence units; LOD, limit of detection.
} 
format and is substrate specific - developed only for detection of catechol-Omethyltransferase (COMT, EC 2.1.1.6) activity [20].

The methyltransferase assay we present employs fluorescence polarization (FP), a well accepted and frequently used technology for high-throughput assays [22]. FP takes advantage of the inverse relationship between the rotational speed of fluorescent molecules in solution and the size of the labeled molecule or complex (for a review, see Ref. [23]). Briefly, the fluorophore absorbs photons of light, resulting in an excited state of the molecule. The duration of the excited state of the fluorophore depends on the identity of the particular fluorophore. For example, for fluorescein, the half-life of the excited state is 9 ns. In the excited state, the fluorophore releases a photon of light that is of a longer wavelength than the excitation light and the fluorophore returns to the ground state. During the excited state, the molecule has time to rotate or spin in solution, depending on its size. Small molecules can rotate and release the light at a different angle than the light was absorbed. Larger molecules do not rotate as quickly, and the light becomes polarized; the angle of release becomes more acute and eventually goes toward zero as molecular mass increases. This polarization is quantified using the ratio of fluorescence measured in the parallel and perpendicular planes relative to the excitation plane. This ratio value is unitless and is referred to as polarization value $(\mathrm{P})$ or, more commonly, is multiplied by 1000 to give millipolarization $(\mathrm{mP})$ values. In general, high $\mathrm{mP}$ values indicate that a fluorophore has a high apparent molecular mass, whereas low $\mathrm{mP}$ values indicate a low apparent molecular mass. Since FP is a ratiometric fluorescence technique, it is subject to less variability than are other non-ratiometric assays.

The competitive fluorescence polarization immunoassay (FPIA) was first described by Dandliker and co-workers and incorporates the use of an antibody to increase the apparent size of a small analyte analog coupled to a fluorophore [24]. In principle, the concentration of unlabeled analytes (e.g., products of enzymatic reactions) can be determined by their ability to compete with fluorescently labeled analogs, commonly called a tracer, for antibody binding. In the absence of product, the tracer is antibody bound, dramatically increasing its apparent mass and decelerating its rotational motion. This reduced molecular rotation results in an increase in FP indicated by high $\mathrm{mP}$ values. When present, analyte competes with tracer for antibody binding, thereby decreasing polarization of the tracer. Competitive FPIA has been widely used for the detection of kinase activity [25-28] as well as in diagnostic tests for small molecule analytes such as metal ions [29], cAMP [30], and "illicit" amphetamines [31]. In this article, the development of a rapid and sensitive homogeneous methyltransferase assay is described using competitive FPIA technology.

AdoMet is considered as the universal methyl donor. AdoMet-dependent methyltransferase reactions yield two products: the methylated molecule and $S$-adenosylhomocysteine (AdoHcy) derived from AdoMet. Our competitive FP assay was developed to detect the AdoHcy product of the methyltransferase reaction and, thus, to measure methyltransferase activity. Since AdoHcy is measured, the assay is considered "universal"; it is capable of detecting enzyme activity of any AdoMet-using methyltransferase. The competitive FPIA assay is a simple one-addition assay requiring only the reaction mixture, fluoresceinated AdoHcy tracer, AdoHcy antibody, and a fluorometer capable of measuring FP. The assay 
makes it feasible and cost-effective to perform high-throughput screening for inhibitors or activators of methyltransferases.

\section{Materials and methods}

\section{Materials}

Black 384-well untreated Costar assay plates were purchased from Corning (Corning, NY, USA). Tris, EDTA, and sodium azide were obtained from Fisher (Fair Lawn, NJ, USA). Dibasic anhydrous sodium phosphate $\left(\mathrm{Na}_{2} \mathrm{HPO}_{4}\right)$ was obtained from Mallinckrodt (Hazelwood, MO, USA). Monobasic monohydrate sodium phosphate $\left(\mathrm{NaH}_{2} \mathrm{PO}_{4}-\mathrm{H}_{2} \mathrm{O}\right)$ was purchased from VWR (West Chester, PA, USA). Sodium chloride $(\mathrm{NaCl})$, magnesium chloride $\left(\mathrm{MgCl}_{2}\right)$, bovine $\gamma$-globulin (BGG), dithiothreitol (DTT), dihydroxybenzoic acid (DBA), 2'-fluoro-3,4-dihydroxy-5-nitrobenzophenone (Ro 41-0960), AdoHcy, and COMT from porcine liver were obtained from Sigma (St. Louis, MO, USA). Phenylmethanesulfonyl fluoride (PMSF) was obtained from Calbiochem (San Diego, CA, USA). AdoMet was obtained from GE Healthcare (Piscataway, NJ, USA). The anti-AdoHcy antibody and fluorescein-AdoHcy conjugate (tracer) were donated by Abbott Laboratories (Abbott Park, IL, USA) as part of the IMx homocysteine FPIA reagent pack (cat. no. 7D29-20) produced by Axis-Shield Diagnostics for Abbott Laboratories.

\section{Methods}

All enzyme reactions and FP assays were performed at a constant laboratory room temperature of $23{ }^{\circ} \mathrm{C}$. For all FP assays, final dilution factors for anti-AdoHcy antibody and tracer were 80 and 160, respectively, in a volume of $50 \mu$ l. All FP measurements were made using the Envision 2102 Multilabel Reader from PerkinElmer (Waltham, MA, USA). A fluorescein isothiocyanate (FITC) single or dual mirror was used. The excitation wavelength was $480 \mathrm{~nm}$ with a bandwidth of $30 \mathrm{~nm}$. The emission wavelength was $535 \mathrm{~nm}$ with a bandwidth of $40 \mathrm{~nm}$. Excitation was performed with 200 flashes.

\section{Mock methyltransferase reactions using AdoMet and AdoHcy}

Mock methyltransferase reactions were performed in 30- $\mu$ l volumes using AdoMet and/or AdoHcy at indicated concentrations in sodium phosphate buffer $(20 \mathrm{mM}, \mathrm{pH} 7.5)$ or Tris buffer (20 mM Tris, pH 8.0, 4 mM EDTA). Here $20 \mu \mathrm{l}$ anti-AdoHcy antibody (1:32 dilution from kit) and tracer (1:64 from kit) were coincubated for $30 \mathrm{~min}$ in either FPIA buffer A (20 $\mathrm{mM}$ sodium phosphate buffer [pH 7.5], $250 \mu \mathrm{g} / \mathrm{ml} \mathrm{BGG}$, and $0.02 \%$ sodium azide) or FPIA buffer B (20mM Tris [pH 8.0], 4 mM EDTA, $1.5 \mathrm{M} \mathrm{NaCl}, 250 \mu \mathrm{g} / \mathrm{ml} \mathrm{BGG,} \mathrm{and} 0.02 \%$ sodium azide). Mock reactions and anti-AdoHcy antibody/tracer complex of matching buffer type were combined, and FP was measured at indicated times.

\section{Competitive FP assay for methyltransferase activity}

COMT endpoint methyltransferase assays were performed using an enzyme reaction volume of $30 \mu \mathrm{l}$ followed by the addition of $20 \mu \mathrm{l}$ anti-AdoHcy antibody/tracer complex. COMT enzyme reactions used 0 to $0.33 \mu \mathrm{g}$ COMT enzyme as indicated, $250 \mu \mathrm{M}$ DBA, and $3 \mu \mathrm{M}$ AdoMet in COMT assay buffer (20 mM sodium phosphate [pH 7.5], $5 \mathrm{mM} \mathrm{MgCl}_{2}$, and 1 mM DTT). Reactions proceeded for the indicated length of time. Anti-AdoHcy antibody and 
tracer were coincubated in FPIA buffer A for $30 \mathrm{~min}$ as before. For the COMT assay, the anti-AdoHcy antibody/tracer solution was supplemented with $25 \mathrm{mM}$ EDTA to stop enzyme activity. FP was measured $1 \mathrm{~h}$ after the addition of anti-AdoHcy antibody/tracer complex to the reaction. For $\mathrm{IC}_{50}$ determination, serial dilutions of the Ro 41-0960 COMT inhibitor were added to the reaction mixture at concentrations ranging from $1.5 \mathrm{nM}$ to $10 \mu \mathrm{M}$ with a final dimethyl sulfoxide (DMSO) concentration of $1 \%$.

\section{Calculations and statistical analysis}

$\mathrm{mP}$ values were calculated from the following equation:

$$
\mathrm{mP}=1000 *\left[\left(I_{\mathrm{S}}-I_{\mathrm{P}}\right) /\left(I_{\mathrm{S}}+I_{\mathrm{P}}\right)\right]
$$

where $I_{\mathrm{S}}$ is the parallel emission intensity and $I_{\mathrm{P}}$ is the perpendicular emission intensity. The $I_{\mathrm{P}}$ value was adjusted by a G-factor multiplier that generated an $\mathrm{mP}$ value of 27 for free fluorescein. Background fluorescence was subtracted from the parallel and perpendicular emission intensities using complete reactions that lack only tracer. Differential $\mathrm{mP}$ is defined as the change in $\mathrm{mP}$ value in the presence and absence of AdoHcy in mock reactions or substrate in the enzyme reactions. The $\mathrm{EC}_{50}$ values for AdoMet and AdoHcy were calculated concentrations that produced an $\mathrm{mP}$ value halfway between the maximum and minimum $\mathrm{mP}$ values of the assay. The $\mathrm{IC}_{50}$ value was defined as the concentration of inhibitor that generated a 50\% reduction in assay signal. $\mathrm{IC}_{50}$ values and Hill slopes were calculated using a four- or three-parameter dose-response (variable slope) equation. All statistical analyses were performed with GraphPad Prism software. Each data point is the average of at least three determinations, and error bars indicating standard deviations are included on all graphs except graphs of differential $\mathrm{mP}$ values (see Figs. 3B and 4B later). Data presented are representative of at least three independent experiments unless otherwise indicated.

\section{Results}

\section{Principle of the assay}

The antibody and tracer components of an FPIA were used in the development of a sensitive and homogeneous assay for determining activity of any AdoMet-using enzyme. This commercial FPIA system quantifies homocysteine levels by converting homocysteine to AdoHcy and then detecting AdoHcy using a competitive FPIA and is intended for use with human serum or plasma [32]. Here assay conditions and FPIA kit components were optimized for sensitive quantization of methyltransferase activity in a format designed for high-throughput screening. Endpoint methyltransferase reactions were incubated with the anti-AdoHcy antibody and fluorescein-AdoHcy conjugate tracer obtained from the commercial reagent kit. As part of the initial large antibody/AdoHcy complex, the tracer generates high FP mP values. AdoHcy generated as a result of methyltransferase activity competes with the tracer for antibody binding. The tracer displaced by AdoHcy is free in solution; therefore, fluorescence of the tracer is depolarized. The decrease in FP is directly proportional to the amount of AdoHcy present and, thus, to methyltransferase activity. 


\section{Antibody/Tracer optimization}

Black 384-well plates and 50- $\mu$ final assay volumes were used in the development of the FP assay. All steps of the assay were performed at $23{ }^{\circ} \mathrm{C}$ for maximal compatibility with highthroughput screening. Dilutions of the original antibody and tracer commercial FPIA components were used to determine optimal concentrations of each component in the assay. For optimal sensitivity to AdoHcy, the amount of tracer was set as low as possible without affecting signal variability. The largest dilution factor for the tracer that produced a total fluorescence signal-to-background ratio greater than 10 and polarization values with a standard deviation of less than $2 \mathrm{mP}$ was 160 (data not shown). In addition, for maximal sensitivity to AdoHcy, the concentration of tracer binding sites should be equal to, or slightly less than, the concentration of tracer. Therefore, an antibody titration in which $20 \mu \mathrm{l}$ antibody diluted into FPIA buffer A was added to $30 \mu \mathrm{l}$ tracer (also diluted in FPIA buffer A at the optimal tracer concentration) was performed (Fig. 1). Peak FP values persisted to an antibody dilution factor of approximately 80 . Therefore, for all subsequent assays, the optimized dilution factors of 160 for tracer and 80 for antibody were selected. These dilution factors are relative to the final 50- $\mu \mathrm{l}$ assay volume. The rate of association of antibody and tracer was determined by mixing $25 \mu \mathrm{l}$ of each in FPIA buffer A at optimal assay concentrations and measuring FP every $5 \mathrm{~min}$ for $1 \mathrm{~h}$ (data not shown). Based on the maximal $\mathrm{mP}$ values obtained, it was determined that antibody and tracer were completely associated after $30 \mathrm{~min}$ of coincubation. Therefore, antibody and tracer were incubated together for at least $30 \mathrm{~min}$ prior to use in the assay. Preforming the antibody/tracer complex has the advantages of eliminating extra variability due to separate additions and reducing development steps to one liquid addition.

\section{FP assay detection of AdoHcy/AdoMet}

This competitive FP assay must be able to specifically detect AdoHcy produced from the methyltransferase reaction. AdoMet, being one of the substrates of methyltransferases, is present at much higher concentrations than AdoHcy and is similar in chemical structure to AdoHcy. Therefore, the ability of both AdoHcy and AdoMet to displace tracer from antibody was evaluated using two different FPIA buffers, designated A and B (see Materials and Methods for composition).

A range of AdoHcy concentrations from $170 \mathrm{nM}$ to $10 \mu \mathrm{M}$ and AdoMet concentrations from 1.7 to $100 \mu \mathrm{M}$ in $30 \mu \mathrm{l}$ were tested by the addition of $20 \mu \mathrm{l}$ antibody/tracer complex under the two different buffer conditions (Fig. 2). As expected, AdoHcy was a much better competitor of tracer in both buffer systems compared with AdoMet. The average calculated $\mathrm{EC}_{50}$ and standard deviation determined for AdoHcy was $18.3 \pm 0.4 \mathrm{nM}$ in FPIA buffer $\mathrm{B}$ and $95 \pm 17$ $\mathrm{nM}$ in FPIA buffer A compared with AdoMet $\mathrm{EC}_{50}$ values of $2.9 \pm 0.5 \mu \mathrm{M}$ in FPIA buffer B and $17.0 \pm 1.2 \mu$ Min FPIA buffer A. Thus, depending on buffer composition, the production of approximately 0.9 to $4.7 \mathrm{pmol}$ AdoHcy can lower the $\mathrm{mP}$ value to the midpoint between maximum and minimum $\mathrm{mP}$ values, whereas it would take 145 to $850 \mathrm{pmol}$ AdoMet to achieve the same results. After $2 \mathrm{~h}$ of incubation time, the ratios of AdoMet $\mathrm{EC}_{50}$ to AdoHcy $\mathrm{EC}_{50}$ were 158 and 180 using FPIA buffers B and A, respectively. These data demonstrate that the antibody is highly selective for binding AdoHcy relative to AdoMet. However, AdoMet concentrations greater than $3 \mu \mathrm{M}$ can significantly interfere with the 
assay by lowering $\mathrm{mP}$ values and reducing sensitivity to AdoHcy. FPIA buffer B conditions produced a 5.2-fold enhanced sensitivity to AdoHcy compared with buffer A. However, it also lowered the maximum $\mathrm{mP}$ value obtainable, resulting in a maximum change in $\mathrm{mP}$ of approximately $180 \mathrm{mP}$, compared with approximately $250 \mathrm{mP}$ under buffer A conditions. We chose to use FPIA buffer A for all subsequent experiments.

\section{Detection of AdoHcy in AdoMet background}

Because AdoMet is present at relatively high concentrations as a required substrate in methyltransferase reactions, the detection of AdoHcy by the FP assay in the presence of AdoMet was examined. To mimic an endpoint methyltransferase assay, AdoHcy was titrated into a proportionally decreasing concentration of AdoMet such that the sum total (AdoHcy + AdoMet) concentration was held constant. AdoHcy titrations from 0 to $80 \mathrm{nM}$ were tested in $1,3,10$, or $30 \mu \mathrm{M}$ total AdoHcy + AdoMet. Here $20 \mu \mathrm{l}$ preincubated antibody/tracer in FPIA buffer A was combined with $30 \mu \mathrm{l}$ AdoHcy/AdoMet mixture, and the change in FP was monitored from 0.5 to $6 \mathrm{~h}$ (Fig. 3A). Here the assay window is the difference between the $\mathrm{mP}$ values obtained in the presence and absence of AdoHcy. A decrease in $\mathrm{mP}$ values was observed in response to increasing concentrations of AdoHcy in the presence of AdoMet. The response of the assay to AdoHcy was linear up to $20 \mathrm{nM}$ AdoHcy, after which the assay began to lose linearity. The nonlinear response to AdoHcy at higher concentrations was expected due to the competitive nature of the FPIA format. Predictably, the assay was more sensitive to AdoHcy when using lower AdoMet concentrations. After 2 h, a 100-mP differential was obtained with 59 and $80 \mathrm{nM}$ AdoHcy in 1 and $3 \mu \mathrm{M}$ AdoMet, respectively. In comparison, only a 50-mP differential was obtained at $80 \mathrm{nM}$ AdoHcy in $10 \mu \mathrm{M}$ AdoMet (Fig. 3B). A high AdoHcy concentration of $320 \mathrm{nM}$ could not achieve even a 50-mP differential in the presence of $30 \mu \mathrm{M}$ AdoMet (data not shown). When comparing the $\mathrm{mP}$ values obtained for AdoHcy titrations in the presence and absence of $1 \mu \mathrm{M}$ AdoMet, the difference between the two is negligible (data not shown). Thus, the use of $1 \mu \mathrm{M}$ AdoMet in the assay does not measurably alter the sensitivity of the FP assay to AdoHcy. At $3 \mu \mathrm{M}$ AdoMet, a small reduction in $\mathrm{mP}$ differential is observed, whereas at $10 \mu \mathrm{M}$ AdoMet, there is a large decrease in the sensitivity of the assay to AdoHcy resulting from antibody crossreactivity with AdoMet. An AdoMet concentration of $3 \mu \mathrm{M}$ was used in all subsequent enzyme reactions. This concentration of AdoMet provided the best balance between having enough AdoMet to allow reasonable catalytic activity and yet not altering $\mathrm{mP}$ values greatly.

An FP measurement time course was performed to determine the stability of the signal and the optimal time to measure FP after adding antibody and tracer to AdoHcy/AdoMet mixtures. A 6-h time course was performed using a range of AdoHcy concentrations from 0 to $320 \mathrm{nM}$ in $3 \mu \mathrm{M}$ AdoHcy/AdoMet as before (Fig. 4A). The time course indicated a slow time-dependent decrease in $\mathrm{mP}$ values with and without AdoHcy. No significant reduction in $\mathrm{mP}$ values was observed in the absence of AdoMet and AdoHcy (data not shown), indicating that the $3-\mu \mathrm{M}$ AdoMet was slowly competing with tracer over time. At lower AdoHcy concentrations ( $\$ 40 \mathrm{nM}$ ), the peak $\mathrm{mP}$ differential was reached at $1 \mathrm{~h}$ (Fig. 4B). At higher concentrations, the 2-h FP measurement time was optimal. At all AdoHcy concentrations, the $\mathrm{mP}$ differential remained relatively constant between 2 and $6 \mathrm{~h}$. In 
subsequent COMT assays, a 1-h FP measurement time was selected for maximal sensitivity to lower AdoHcy concentrations.

\section{FP assay validation using the COMT enzyme and inhibitor with known $\mathrm{IC}_{50}$}

To validate the assay's ability to detect and quantitate methyltransferase enzyme activity, the methyltransferase COMT and a known selective inhibitor of COMT activity were used in proof-of-principle experiments.

In the presence of AdoMet and magnesium, COMT inactivates biologically active catechols through $O$-methylation [33]. COMT has a range of catechol substrates, including dopamine, norepinephrine, 3-(3,4-dihydroxyphenyl)-L-alanine (L-DOPA), and catecholic steroids [3336]. There are also several catechol-like and non-catechollike inhibitors of COMT activity [37-39]. To demonstrate the utility of this assay to detect COMT activity, a common substrate for COMT assays, DBA, was used along with Ro 41-0960, a potent COMT inhibitor.

\section{COMT enzyme titration and time course}

For all COMT activity assays, the concentrations of DBA and AdoMet substrates in the assay were 250 and $3 \mu \mathrm{M}$, respectively. These concentrations were selected so as to equal published $K_{\mathrm{m}}$ values for these substrates [40-42]. A range of COMT amounts from 12 to $333 \mathrm{ng}$ per reaction were tested in the presence and absence of DBA substrate using a 10min reaction time (Fig. 5). All but the lowest concentration exhibited detectible methyltransferase activity as measured by the FP assay. There was a linear inverse relationship between $\mathrm{mP}$ value and amount of COMT, with $333 \mathrm{ng}$ COMT producing an 80$\mathrm{mP}$ decrease in FP relative to the no-substrate control (Fig. 5A). The $\mathrm{mP}$ values for each concentration were converted to Ado-Hcy concentration based on a standard AdoHcy curve generated in mock reactions lacking only DBA (Fig. 5B). At 333 ng enzyme per well, the $80-\mathrm{mP}$ differential corresponds to approximately $52 \mathrm{nM}$ (2.6 pmol) AdoHcy generated. This represents only $1.7 \%$ conversion of AdoMet to AdoHcy. COMT has been reported to be inhibited by AdoHcy with a $K_{\mathrm{i}}$ of $1 \mu \mathrm{M}$ [40]. Therefore, the $52 \mathrm{nM}$ AdoHcy generated in this COMT FP assay should not significantly affect the rate of the reaction.

A time course of COMT activity was performed using $333 \mathrm{ng}$ enzyme per reaction (Fig. 6). At each time point, the methyltransferase reaction was stopped with 10 mM EDTA as part of the antibody/tracer solution. FP measurements were taken after $1 \mathrm{~h}$. A time-dependent decrease in $\mathrm{mP}$ values that was dependent on the presence of the DBA substrate was observed. Most COMT enzyme activity occurred during the first $30 \mathrm{~min}$, with $50 \%$ of the maximum $\mathrm{mP}$ differential produced during the first $5 \mathrm{~min}$. This time-dependent loss of COMT activity was similar to that in another report of a COMT activity assay using the same source of enzyme [18]. The linear range with respect to time was limited to the first 15 $\min$ of the reaction.

To further validate the competitive FP methyltransferase assay, the $\mathrm{IC}_{50}$ of a wellcharacterized COMT inhibitor was determined using the assay. Ro 41-0960 is a well-known, non-catechol-like selective inhibitor of COMT activity. Its published $\mathrm{IC}_{50}$ range is between 
5 and $42 \mathrm{nM}$, as determined from analysis of O-methylated product using GC/MS [39]. In the presence of a range of Ro 41-0960 concentrations, enzyme activity assays using $333 \mathrm{ng}$ COMT and a 10-min reaction time were performed and stopped with the antibody/tracer/ EDTA in FPIA buffer A and after $1 \mathrm{~h}$, and then FP was measured (Fig. 7). The average $\mathrm{IC}_{50}$ value and standard deviation derived from three separate experiments was $12 \pm 9 \mathrm{nM}$. Thus, the $\mathrm{IC}_{50}$ value determined with this COMT FP assay was consistent with the range of $\mathrm{IC}_{50}$ values reported in the literature. $\mathrm{The} \mathrm{IC}_{50}$ values for this experiment were 5.0, 9.0, and 22 $\mathrm{nM}$. Thus, the standard error was $5 \mathrm{nM}$, or $40 \%$ of the average value, which is comparable to the standard errors reported for the same inhibitor in the GC/MS COMT assay in which 17 to $53 \%$ standard errors was reported [39].

\section{Discussion}

Methyltransferase activity has been determined by quantification of reaction products using a variety of methods. A majority of the assays require separation of labeled reaction products from labeled substrate. Currently, HPLC is widely employed for separation in conjunction with detection of fluorescent [43-52] or radiolabeled [53,54] product, UV detection [55-58], electrochemical detection [59-61], colorimetric detection [62], or mass spectrometry [63]. Assays that require physical separation of product from substrate are not well suited for high-throughput purposes due to the number of manipulations and amount of time required for the separation process. In this article, we have detailed a homogeneous, inexpensive, and sensitive competitive FP assay of methyltransferase activity optimized for high-throughput screening. Unlike other routinely used methods, no separation steps are required.

The components of a commercial diagnostic kit were used to develop a competitive FP assay for methyltransferase activity. The AdoHcy-fluorescein tracer and anti-AdoHcy antibody from the kit were titrated to find the optimal concentration of each. Dilutions were chosen to maximize sensitivity to AdoHcy. The low concentration of tracer generated total relative fluorescence units (RFU) comparable to approximately $0.5 \mathrm{nM}$ fluorescein (data not shown). Background fluorescence at this concentration of tracer was not significant for the described enzyme assays. However, other potential methyltransferase reactions may require a somewhat higher concentration of tracer (and thus antibody as well) to minimize the impact of background fluorescence on measured FP. The theoretical impact of increasing tracer and antibody concentration would be to lessen sensitivity to AdoHcy.

Given that in a methyltransferase reaction both AdoMet and AdoHcy are present, with the former being present at a much higher concentration than the latter, the selectivity of the anti-AdoHcy antibody was evaluated. The change in FP of the tracer complexed to antibody was tested in response to AdoMet and AdoHcy. The $\mathrm{EC}_{50}$ values for disrupting the complex were 95 and 17,000 $\mathrm{nM}$ for AdoHcy and AdoMet, respectively, using FPIA buffer A. Using FPIA buffer B, the $\mathrm{EC}_{50}$ values were 18 and $2900 \mathrm{nM}$ for AdoHcy and AdoMet, respectively. Thus, the $\mathrm{EC}_{50}$ ratios of AdoMet to AdoHcy were 158 and 180 under the two different buffer conditions. Depending on buffer composition, the production of approximately 0.9 to $4.7 \mathrm{pmol}$ of AdoHcy can lower the $\mathrm{mP}$ value to the midpoint between 
maximum and minimum $\mathrm{mP}$ values. This FP assay takes advantage of this window of differential binding of AdoHcy and AdoMet to the antibody.

The use of FPIA buffer B made the assay 5.2 times more sensitive to AdoHcy but also more sensitive to AdoMet. Furthermore, the peak mP value decreased by approximately 75 compared with that using FPIA buffer A. If substrate conversion is low, FPIA buffer B may be desired for increased sensitivity to AdoHcy. However, if a larger assay window is desired, FPIA buffer A allows for higher mP value differentials. Further alteration of buffer composition after the enzyme reaction is terminated can make the assay better suited for the needs of the particular enzyme assay.

To determine whether the differential reactivity of AdoMet and AdoHcy with antibody could be exploited to measure methyltransferase activity, mock endpoint reactions were employed. These mock reactions were designed to determine the sensitivity of the assay to AdoHcy in the presence of different concentrations of AdoMet. In these experiments, the total concentration of AdoMet + AdoHcy was kept constant by increasing AdoHcy concentration and proportionally decreasing AdoMet concentration. Here 59 and $80 \mathrm{nM}$ AdoHcy generated a 100-mP decrease in FP in the presence of 1 and $3 \mu$ MAdoMet, respectively. In comparison, only a 50-mP differential was obtained at $80 \mathrm{nM}$ AdoHcy in 10 $\mu \mathrm{M}$ AdoMet. A high AdoHcy concentration of $320 \mathrm{nM}$ could not achieve even a 50-mP differential in the presence of $30 \mu \mathrm{M}$ AdoMet. Thus, the optimal concentrations of AdoMet that were well tolerated in this assay were 1 to $3 \mu \mathrm{M}$, with no or low impact on the sensitivity to AdoHcy.

AdoMet concentration is a significant factor in the assay given that AdoMet is also able to displace tracer from the AdoHcy antibody, albeit at much higher concentrations than AdoHcy. AdoMet at $3 \mu \mathrm{M}$ or higher causes a time-dependent decrease in $\mathrm{mP}$ value in the absence of AdoHcy, a phenomenon not displayed in the absence of both AdoMet and AdoHcy. Despite this slow competition with tracer by AdoMet, a mere $2.7 \%$ conversion of 3 $\mu \mathrm{M}$ AdoMet into AdoHcy is enough to produce a $100-\mathrm{mP}$ differential compared with control. The sensitivity of this FP assay means that it is not necessary to use high AdoMet concentrations that might be needed in other less sensitive assays. In addition, the sensitivity of this assay to low nanomolar concentrations of AdoHcy avoids the problem of product inhibition by AdoHcy known to occur with methyltransferases [40,64-66].

COMT enzyme reactions were performed to test the ability of the FP assay to measure enzyme activity of a methyltransferase. In the FP assay using terminated COMT reactions, FP values decreased proportionally with increasing enzyme concentration and reaction time. Under the conditions used for this COMT assay, only 1.7\% of the AdoMet was converted to AdoHcy. In addition, $\mathrm{IC}_{50}$ values determined using the competitive FP assay of a welldescribed, potent COMT inhibitor were comparable to published values obtained from GC/MS analysis.

There have been a small number of reports of universal assays for AdoMet-dependent methyltransferases in the literature [17-19]. All of these assays are enzyme coupled. Specifically, AdoHcy reaction product is further metabolized by AdoHcy hydrolase or 
AdoHcy nucleosidase to Hcy or $S$-ribosylhomocysteine, respectively. The product is then directly assayed or further enzymatically manipulated to produce a different product. There are several limitations to these enzyme-coupled assays. The sensitivity of each of these reported assays to initial reaction product is low, with a limit of detection (LOD) for AdoHcy in the single-digit micromolar range, compared with approximately $5 \mathrm{nM}(0.15$ pmol) in the competitive FP assay. Thus, the described assay is approximately 1000 -fold more sensitive to AdoHcy than are the enzyme-coupled formats. With each additional enzymatic step, the ratio of end product to initial AdoHcy decreases due to incomplete product conversion, limiting the sensitivity of the assay. In addition, these enzyme-coupled assays are subject to false positives in a compound screen for inhibitors of methyltransferase due to inhibition of the developing enzyme. In the fluorescence-based assay [18], a noncommercial fluorescent reporter molecule that uses a disulfide tether as a linker needed to be synthesized. Therefore, reducing agents that often are present and/or required in enzyme reactions are incompatible with the assay. An additional requirement of the colorimetric enzyme-coupled assay is bubbling nitrogen gas through the buffer to protect the thiol group of homocysteine [17]. Enzyme-coupled assays are more complex to optimize and troubleshoot compared with an FPIA. Also, the additional steps required by these assays make them less amenable to high-throughput screening. The development enzyme(s) required for these assays also increases the cost per well.

A recently published report of a competitive ELISA-based immunoassay for AdoHcy could be used as a universal assay for AdoMet-using methyltransferases [67]. Although this ELISA assay is highly sensitive to AdoHcy (LOD $<0.1 \mathrm{pmol}$ ), it is not homogeneous, requiring several washing steps. ELISA-type assays are not ideal for high-throughput screening due to inherently higher variability than homogeneous assays, difficulties in miniaturizing them to 384- and 1536-well plate formats, and the fact that they are very labor intensive due to the wash steps. Other assays have been reported as being high-throughput methyltransferase assays but are specific to a particular substrate and thus are enzyme specific $[20,21]$. Unlike these assays, the FP assay is "universal" because it has the potential to quantify activity of any AdoMet-using methyltransferase. In addition, the cost of the described assay would be less than 10 cents per well for the antibody and tracer. Thus, the competitive FP assay is miniaturizable, homogeneous, very sensitive, low cost, and it requires only commercially available reagents and equipment.

In the current form, this FPIA has some limitations. The major limitation is the crossreactivity of the anti-AdoHcy antibody with AdoMet. This property of the antibody limits the amount of AdoMet that can be used in the assay. Depending on the $K_{\mathrm{m}}$ for AdoMet of a particular methyltransferase, this may limit the activity of the enzyme or require the use of more enzyme. A known problem with any fluorescein-based assay is the interference of some test compounds that are also fluorescent and typically present in micromolar concentrations. These fluorescent compounds interfere with accurate measurement of fluorescein. For this FPIA, fluorescent compounds could generate false positives in a screen for methyltransferase inhibitors. False positives due to fluorescence of the compound can be easily eliminated by either comparing the raw RFU obtained from the test compound well with control wells or testing the compound in the absence of enzyme. For compounds with a 
low amount of fluorescence and tested in low-throughput mode, the problem potentially can be circumvented by subtracting compound fluorescence from the signal. Using a higher concentration of tracer (and thus antibody) would also make the assay more resistant to interference from fluorescent test compounds but also proportionally less sensitive to AdoHcy. Alternatively, screening compounds at a lower concentration of compound would be expected to decrease false-positive/negative rates while selecting for more potent inhibitors. It has been reported that assays with red-shifted fluorophores (emission peak at a higher wavelength) have a lower incidence of false positives in a diverse compound library screen compared with the use of fluorescein in the assay [68]. Replacing the fluorescein tag on the tracer with a more red-shifted fluorophore should significantly reduce the number of compounds in a high-throughput screen that interfere with the FP measurement.

Another challenge in developing a methyltransferase assay using this method is stopping the enzyme reaction without affecting antibody integrity. Many methyltransferases are not magnesium dependent, and so it is more of a challenge to terminate the reaction in a homogeneous, high-throughput manner that also preserves antibody function. Due to the 1to 2-h time delay for peak tracer displacement, a continuous kinetic version of the assay will not accurately reflect the status of the enzyme reaction. Potential methods of stopping the reaction would be to add a low concentration of SDS to inactivate the enzyme prior to adding antibody/tracer. In some cases, a concentration of SDS may be found whereby the purified enzyme is inactivated, but the antibody is protected from the SDS by BGG or BSA present in the FPIA buffer. Another method is to stop a reaction with the addition of acid or base to shift the $\mathrm{pH}$ and then adjust it back to neutral with a modified FPIA buffer. Also, the use of chelating agents such as EDTA, a technique used in this report, is capable of stopping methyltransferases that are dependent on divalent cations for activity.

\section{Acknowledgments}

The authors thank Abbott Laboratories (Abbott Park, IL, USA) for the generous donation of FPIA reagents. In addition, the authors thank Li-An Yeh for helpful discussions and critical reading of the manuscript. This work was supported in part by a grant from the Golden LEAF Foundation and funds from the State of North Carolina.

\section{References}

1. Cantoni GL. Biological methylation: Selected aspects. Annu Rev Biochem. 1975; 44:435-451. [PubMed: 1094914]

2. Chiang PK, Gordon RK, Tal J, Zeng GC, Doctor BP, Pardhasaradhi K, McCann PP. SAdenosylmethionine and methylation. FASEB J. 1996; 10:471-480. [PubMed: 8647346]

3. Fujioka M. Mammalian small molecule methyltransferases: Their structural and functional features. Intl J Biochem. 1992; 24:1917-1924.

4. Borchardt RT. S-Adenosyl-L-methionine-dependent macromolecule methyltransferases: Potential targets for the design of chemotherapeutic agents. J Med Chem. 1980; 23:347-357. [PubMed: 6991690]

5. Hermann A, Gowher H, Jeltsch A. Biochemistry and biology of mammalian DNA methyltransferases. Cell Mol Life Sci. 2004; 61:2571-2887. [PubMed: 15526163]

6. Trievel RC. Structure and function of histone methyltransferases. Crit Rev Eukaryotic Gene Expr. 2004; 14:147-169.

7. Grillo MA, Colombatto S. S-Adenosylmethionine and protein methylation. Amino Acids. 2005; 28:357-362. [PubMed: 15838589] 
8. Martin C, Zhang Y. The diverse functions of histone lysine methylation. Nat Rev Mol Cell Biol. 2005; 6:838-849. [PubMed: 16261189]

9. Klose RJ, Zhang Y. Regulation of histone methylation by demethylimination and demethylation. Nat Rev Mol Cell Biol. 2007; 8:307-318. [PubMed: 17342184]

10. Siedlecki P, Zielenkiewicz P. Mammalian DNA methyltransferases. Acta Biochim Pol. 2006; 53:245-256. [PubMed: 16582985]

11. Milne TA, Briggs SD, Brock HW, Martin ME, Gibbs D, Allis CD, Hess JL. MLL targets SET domain methyltransferase activity to Hox gene promoters. Mol Cell. 2002; 10:1107-1117. [PubMed: 12453418]

12. Feinberg AP, Vogelstein B. Hypomethylation distinguishes genes of some human cancers from their normal counterparts. Nature. 1983; 301:89-92. [PubMed: 6185846]

13. Gama-Sosa MA, Slagel VA, Trewyn RW, Oxenhandler R, Kuo KC, Gehrke CW, Ehrlich M. The 5-methylcytosine content of DNA from human tumors. Nucleic Acids Res. 1983; 11:6883-6894. [PubMed: 6314264]

14. Lapeyre JN, Becker FF. 5-Methylcytosine content of nuclear DNA during chemical hepatocarcinogenesis and in carcinomas which result. Biochem Biophys Res Commun. 1979; 87:698-705. [PubMed: 454420]

15. Nakhasi HL, Lynch KR, Dolan KP, Unterman RD, Feigelson P. Covalent modification and repressed transcription of a gene in hepatoma cells. Proc Natl Acad Sci USA. 1981; 78:834-837. [PubMed: 7015332]

16. Hamamoto R, Furukawa Y, Morita M, Iimura Y, Silva FP, Li M, Yagyu R, Nakamura Y. SMYD3 encodes a histone methyltransferase involved in the proliferation of cancer cells. Nat Cell Biol. 2004; 6:731-740. [PubMed: 15235609]

17. Hendricks CL, Ross JR, Pichersky E, Noel JP, Zhou ZS. An enzyme-coupled colorimetric assay for $S$-adenosylmethionine-dependent methyltransferases. Anal Biochem. 2004; 326:100-105. [PubMed: 14769341]

18. Wang C, Leffler S, Thompson DH, Hrycyna CA. A general fluorescence-based coupled assay for $S$-adenosylmethionine-dependent methyltransferases. Biochem Biophys Res Commun. 2005; 331:351-356. [PubMed: 15845399]

19. Dorgan KM, Wooderchak WL, Wynn DP, Karschner EL, Alfaro JF, Cui Y, Zhou ZS, Hevel JM. An enzyme-coupled continuous spectrophotometric assay for $S$-adenosylmethionine-dependent methyltransferases. Anal Biochem. 2006; 350:249-255. [PubMed: 16460659]

20. Kurkela M, Siiskonen A, Finel M, Tammela P, Taskinen J, Vuorela P. Microplate screening assay to identify inhibitors of human catechol- $O$-methyltransferase. Anal Biochem. 2004; 331:198-200. [PubMed: 15246016]

21. Woo YH, Rajagopalan PT, Benkovic SJ. A nonradioactive DNA methyltransferase assay adaptable to high-throughput screening. Anal Biochem. 2005; 340:336-340. [PubMed: 15840507]

22. Owicki JC. Fluorescence polarization and anisotropy in high throughput screening: Perspectives and primer. J Biomol Screen. 2000; 5:297-306. [PubMed: 11080688]

23. Jameson DM, Croney JC. Fluorescence polarization: Past, present, and future. Comb Chem High Throughput Screen. 2003; 6:167-173. [PubMed: 12678695]

24. Dandliker WB, Kelly RJ, Dandliker J, Farquahar J, Levin J. Fluorescence polarization immunoassay: Theory and experimental method. Immunochemistry. 1973; 10:219-227. [PubMed: 4580370]

25. Beasley JR, McCoy PM, Walker TL, Dunn DA. Miniaturized, ultra-high throughput screening of tyrosine kinases using homogeneous, competitive fluorescence immunoassays. Assay Drug Dev Technol. 2004; 2:141-151. [PubMed: 15165510]

26. Seethala R, Menzel R. A fluorescence polarization competition immunoassay for tyrosine kinases. Anal Biochem. 1998; 255:257-262. [PubMed: 9451512]

27. Scott JE, Carpenter JW. A homogeneous assay of kinase activity that detects phosphopeptide using fluorescence polarization and zinc. Anal Biochem. 2003; 316:82-91. [PubMed: 12694730]

28. Turek TC, Small EC, Bryant RW, Hill WA. Development and validation of a competitive AKT serine/threonine kinase fluorescence polarization assay using a product-specific anti-phosphoserine antibody. Anal Biochem. 2001; 299:45-53. [PubMed: 11726183] 
29. Johnson DK. Fluorescence polarization immunoassays for metal ions. Comb Chem High Throughput Screen. 2003; 6:245-255. [PubMed: 12678703]

30. Hesley J, Daijo J, Ferguson AT. Stable, sensitive, fluorescence-based method for detecting camp. BioTechniques. 2002; 33:691-694. [PubMed: 12238779]

31. Cody JT, Schwarzhoff R. Fluorescence polarization immunoassay detection of amphetamine, methamphetamine, and illicit amphetamine analogues. J Anal Toxicol. 1993; 17:23-33. [PubMed: 8429622]

32. Shipchandler MT, Moore EG. Rapid, fully automated measurement of plasma homocyst(e)ine with the Abbott IMx analyzer. Clin Chem. 1995; 41:991-994. [PubMed: 7600701]

33. Axelrod J, Tomchick R. Enzymatic $O$-methylation of epinephrine and other catechols. J Biol Chem. 1958; 233:702-705. [PubMed: 13575440]

34. Axelrod J. Methylation reactions in the formation and metabolism of catecholamines and other biogenic amines. Pharmacol Rev. 1966; 18:95-113. [PubMed: 5323771]

35. Ball P, Knuppen R. Catecholoestrogens (2- and 4-hydroxyoestrogens): Chemistry, biogenesis, metabolism, occurrence, and physiological significance. Acta Endocrinol Suppl (Copenh). 1980; 232:1-127. [PubMed: 6770572]

36. Guldberg HC, Marsden CA. Catechol- $O$-methyl transferase: Pharmacological aspects and physiological role. Pharmacol Rev. 1975; 27:135-206. [PubMed: 1103160]

37. Backstrom R, Honkanen E, Pippuri A, Kairisalo P, Pystynen J, Heinola K, Nissinen E, Linden IB, Mannisto PT, Kaakkola S, Pohto P. Synthesis of some novel potent and selective catechol- $O$ methyltransferase inhibitors. J Med Chem. 1989; 32:841-846. [PubMed: 2704029]

38. Chen D, Wang CY, Lambert JD, Ai N, Welsh WJ, Yang CS. Inhibition of human liver catechol- $O$ methyltransferase by tea catechins and their metabolites: Structure-activity relationship and molecular-modeling studies. Biochem Pharmacol. 2005; 69:1523-1531. [PubMed: 15857617]

39. van Duursen MB, Sanderson JT, de Jong PC, Kraaij M, van den Berg M. Phytochemicals inhibit catechol- $O$-methyltransferase activity in cytosolic fractions from healthy human mammary tissues: Implications for catechol estrogen-induced DNA damage. Toxicol Sci. 2004; 81:316-324. [PubMed: 15254334]

40. Rivett AJ, Roth JA. Kinetic studies on the $O$-methylation of dopamine by human brain membranebound catechol $O$-methyltransferase. Biochemistry. 1982; 21:1740-1742. [PubMed: 7082642]

41. Flohe L, Schwabe KP. Kinetics of purified catechol $O$-methyltransferase. Biochim Biophys Acta. 1970; 220:469-476. [PubMed: 5499627]

42. Nikodejevic B, Senoh S, Daly JW, Creveling CR. Catechol- $O$-methyltransferase: II. A new class of inhibitors of catechol- $O$-methyltransferase; 3,5-Dihydroxy-4-methoxybenzoic acid and related compounds. J Pharmacol Exp Ther. 1970; 174:83-93. [PubMed: 5432229]

43. Okada Y, Zaitsu K, Ohtsubo K, Nohta H, Ohkura Y. Fluorimetric assay for catechol- $O$ methyltransferase. Chem Pharm Bull (Tokyo). 1981; 29:1670-1673. [PubMed: 7296717]

44. Aoyama N, Tsunoda M, Imai K. Improved assay for catechol- $O$-methyltransferase activity utilizing norepinephrine as an enzymatic substrate and reversed-phase high-performance liquid chromatography with fluorescence detection. J Chromatogr A. 2005; 1074:47-51. [PubMed: 15941038]

45. Hirano Y, Tsunoda M, Funatsu T, Imai K. Rapid assay for catechol- $O$-methyltransferase activity by high-performance liquid chromatography-fluorescence detection. J Chromatogr B. 2005; 819:41-46.

46. Masuda M, Tsunoda M, Imai K. High-performance liquid chromatography-fluorescent assay of catechol- $O$-methyltransferase activity in rat brain. Anal Bioanal Chem. 2003; 376:1069-1073. [PubMed: 12904944]

47. Itoh MT, Hattori A, Sumi Y. Hydroxyindole- $O$-methyltransferase activity assay using highperformance liquid chromatography with fluorometric detection: Determination of melatonin enzymatically formed from $N$-acetyl serotonin and $S$-adenosyl-L-methionine. J Chromatogr B. 1997; 692:217-221.

48. Sano A, Endo N, Takitani S. Fluorometric assay of rat brain $\mathrm{N}$-methyltransferase with 4methylnicotinamide. Biol Pharm Bull. 1993; 16:304-306. [PubMed: 8364477] 
49. Garras A, Djurhuus R, Christensen B, Lillehaug JR, Ueland PM. A nonradioactive assay for N 5methyltetrahydrofolate-homocysteine methyltransferase (methionine synthase) based on $o$ phthaldialdehyde derivatization of methionine and fluorescence detection. Anal Biochem. 1991; 199:112-118. [PubMed: 1807154]

50. Zurcher G, Da Prada M, Dingemanse J. Assessment of catechol- $O$-methyltransferase activity and its inhibition in erythrocytes of animals and humans. Biomed Chromatogr. 1996; 10:32-36. [PubMed: 8821869]

51. Schusler-van Hees MT, Beijersbergen van Henegouwen GM. Determination of catecholamines and $O$-methylated metabolites by reversed-phase high-performance liquid chromatography with fluorimetric detection and its application to enzyme kinetics. J Chromatogr. 1980; 196:101-108. [PubMed: 7400287]

52. Smit NP, Pavel S, Kammeyer A, Westerhof W. Determination of catechol $O$-methyltransferase activity in relation to melanin metabolism using high-performance liquid chromatography with fluorimetric detection. Anal Biochem. 1990; 190:286-291. [PubMed: 2291472]

53. Lautala P, Ulmanen I, Taskinen J. Radiochemical high-performance liquid chromatographic assay for the determination of catechol $O$-methyltransferase activity towards various substrates. J Chromatogr B. 1999; 736:143-151.

54. Nissinen E. Determination of catechol- $O$-methyltransferase activity in brain tissue by highperformance liquid chromatography with online radiochemical detection. Anal Biochem. 1985; 144:247-252. [PubMed: 3985318]

55. Oselin K, Anier K, Tamm R, Kallassalu K, Maeorg U. Determination of thiopurine $S$ methyltransferase (TPMT) activity by comparing various normalization factors: Reference values for Estonian population using HPLC-UV assay. J Chromatogr B. 2006; 834:77-83.

56. Grazia Alessandri M, Celati L, Battini R, Baldinotti F, Item C, Leuzzi V, Cioni G. HPLC assay for guanidinoacetate methyltransferase. Anal Biochem. 2004; 331:189-191. [PubMed: 15246013]

57. Anglicheau D, Sanquer S, Loriot MA, Beaune P, Thervet E. Thiopurine methyltransferase activity: New conditions for reversed-phase high-performance liquid chromatographic assay without extraction and genotypic-phenotypic correlation. J Chromatogr B. 2002; 773:119-127.

58. Beaudouin C, Haurat G, Fraisse L, Souppe J, Renaud B. Assay of phenylethanolamine $N$ methyltransferase activity using high-performance liquid chromatography with ultraviolet absorbance detection. J Chromatogr. 1993; 613:51-58. [PubMed: 8458902]

59. Borchardt RT, Hegazi MF, Schowen RL. Determination of $O$-methylated metabolites of cathecholamines using high-performance liquid chromatography and electrochemical detection. J Chromatogr. 1978; 152:253-259. [PubMed: 649747]

60. Reenila I, Tuomainen P, Mannisto PT. Improved assay of reaction products to quantitate catechol$O$-methyltransferase activity by high-performance liquid chromatography with electrochemical detection. J Chromatogr B. 1995; 663:137-142.

61. Allen E, Myers C, Frank D, Pettigrew A, Thompson S, Blumer JL. Application of an organic solvent extraction to the determination of catechol- $O$-methyltransferase activity by highperformance liquid chromatography in human mononuclear cells. J Chromatogr. 1992; 578:175188. [PubMed: 1400795]

62. Bailey K, Cowling R, Tan EW, Webb D. A colorimetric assay for catechol- $O$-methyltransferase. Bioorg Med Chem. 2004; 12:595-601. [PubMed: 14738970]

63. Salyan ME, Pedicord DL, Bergeron L, Mintier GA, Hunihan L, Kuit K, Balanda LA, Robertson BJ, Feder JN, Westphal R, Shipkova PA, Blat Y. A general liquid chromatography/mass spectroscopy-based assay for detection and quantitation of methyltransferase activity. Anal Biochem. 2006; 349:112-117. [PubMed: 16325755]

64. Ball P, Knuppen R, Haupt M, Breuer H. Kinetic properties of a soluble catechol $O$ methyltransferase of human liver. Eur J Biochem. 1972; 26:560-569. [PubMed: 5025932]

65. Zhu BT, Patel UK, Cai MX, Conney AH. $O$-Methylation of tea polyphenols catalyzed by human placental cytosolic catechol- $O$-methyltransferase. Drug Metab Dispos. 2000; 28:1024-1030. [PubMed: 10950844]

66. Lotta T, Vidgren J, Tilgmann C, Ulmanen I, Melen K, Julkunen I, Taskinen J. Kinetics of human soluble and membrane-bound catechol $O$-methyltransferase: A revised mechanism and description 
of the thermolabile variant of the enzyme. Biochemistry. 1995; 34:4202-4210. [PubMed: 7703232]

67. Capdevila A, Burk RF, Freedman J, Frantzen F, Alfheim I, Wagner C. A simple rapid immunoassay for $S$-adenosylhomocysteine in plasma. J Nutr Biochem. in press.

68. Turek-Etienne TC, Small EC, Soh SC, Xin TA, Gaitonde PV, Barrabee EB, Hart RF, Bryant RW. Evaluation of fluorescent compound interference in 4 fluorescence polarization assays: 2 kinases, 1 protease, and 1 phosphatase. J Biomol Screen. 2003; 8:176-184. [PubMed: 12844438] 


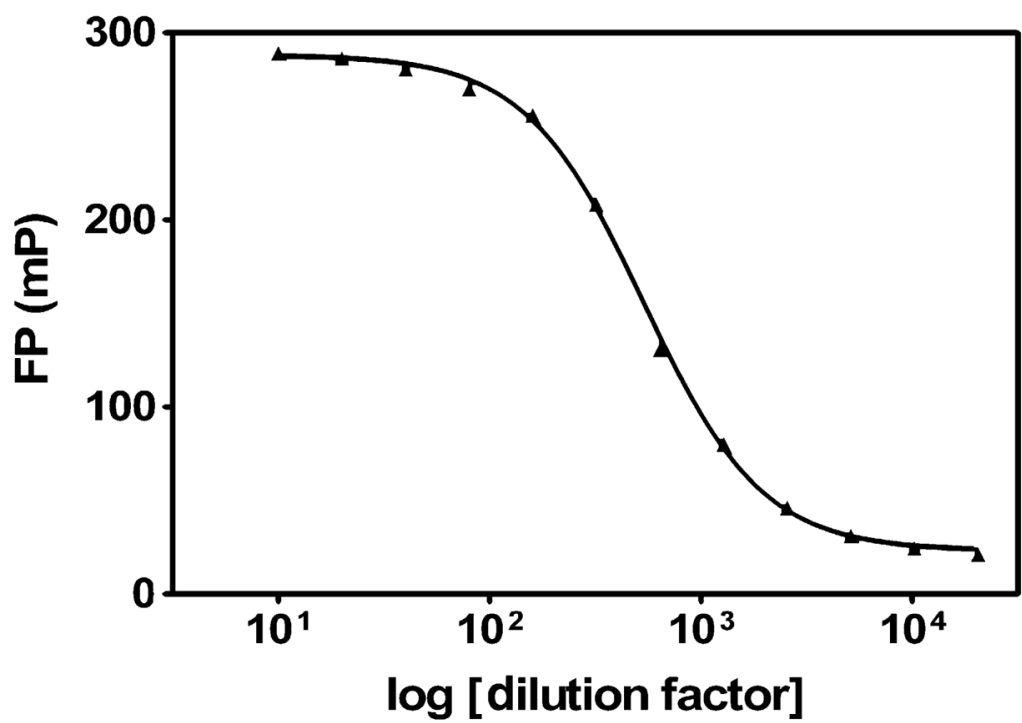

Fig. 1.

Effect of AdoHcy antibody concentration on fluorescence polarization of AdoHcy tracer. Here 20- $\mu$ l AdoHcy antibody dilutions were added to $30 \mu \mathrm{l}$ tracer. FP was measured 30 min postaddition. Final dilution factors for anti-AdoHcy antibody in $50 \mu$ are indicated; that of tracer is 160 . Data are representative of two independent experiments. 

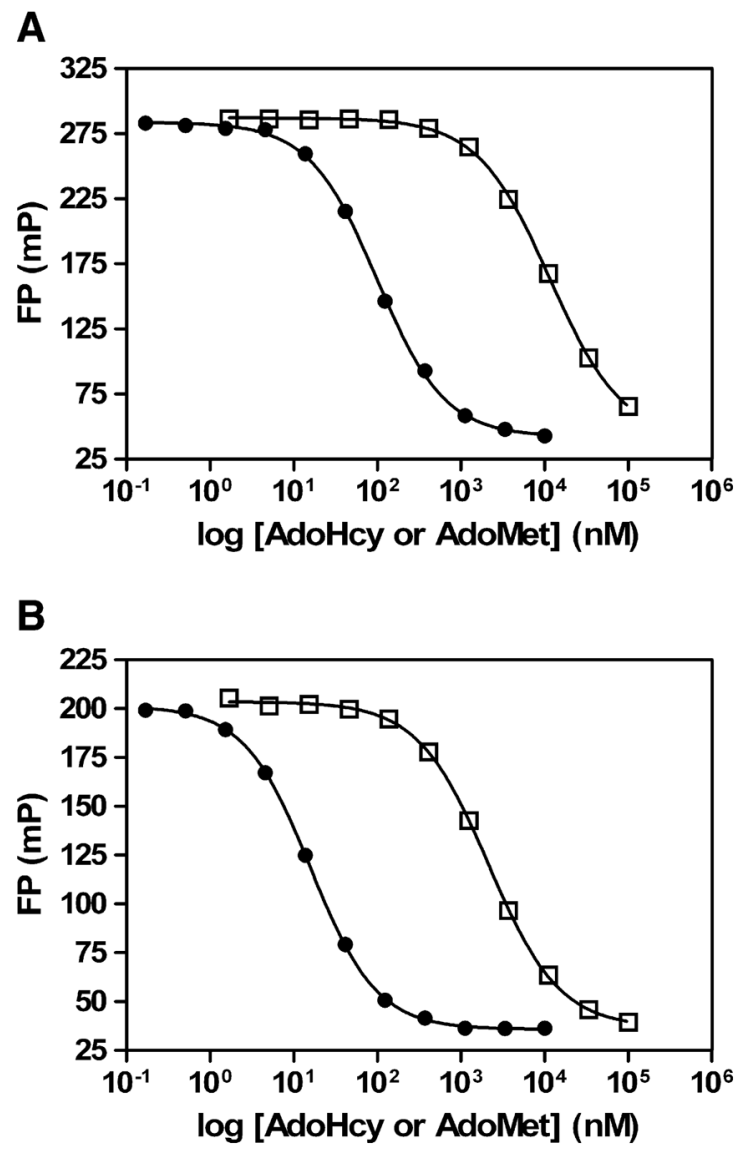

Fig. 2.

Displacement of AdoHcy tracer from anti-AdoHcy antibody by unlabeled AdoHcy and AdoMet using FPIA buffer A (A) and FPIA buffer B (B) conditions. The assay was conducted by adding $30 \mu \mathrm{l}$ of AdoHcy (O) or AdoMet $(\square)$ at the indicated concentrations to $20 \mu \mathrm{l}$ antibody/tracer complex, incubating for $2 \mathrm{~h}$, and measuring FP. 
A

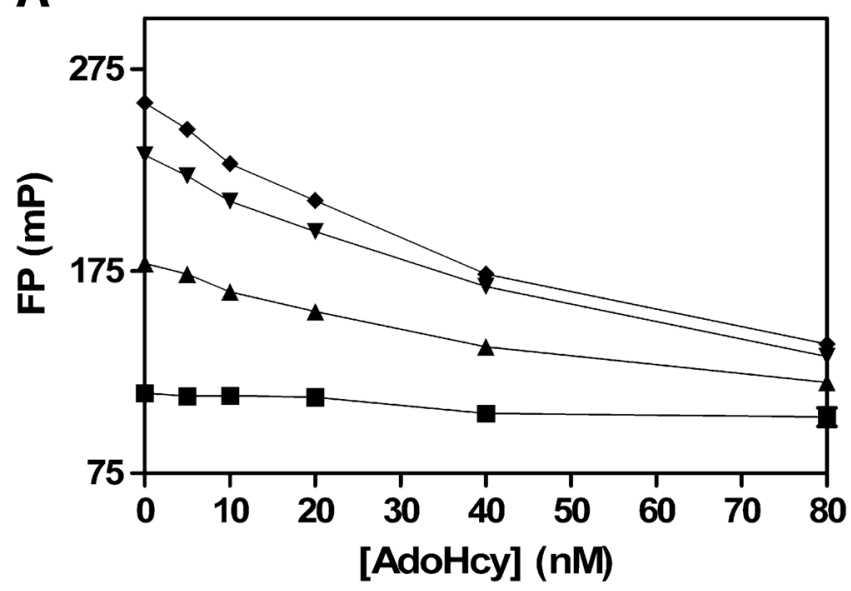

B

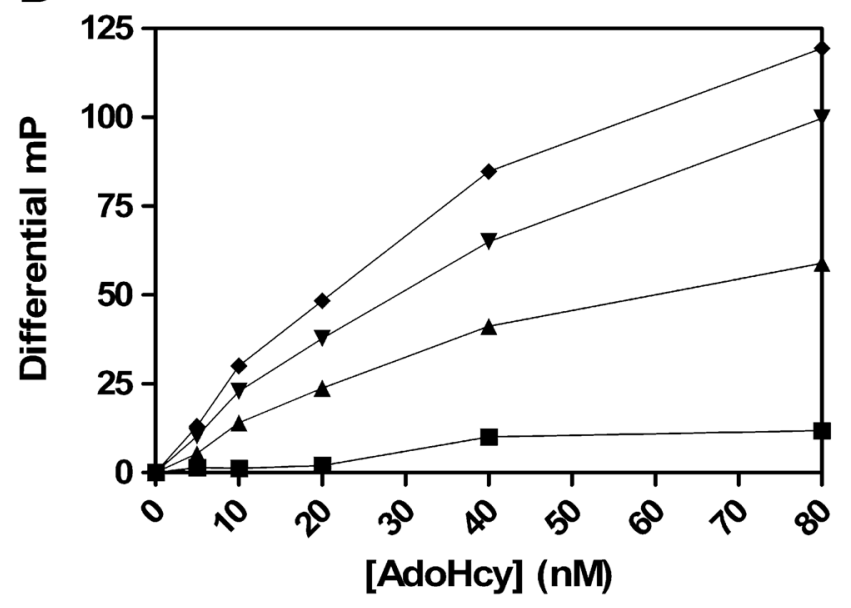

Fig. 3.

Mock methyltransferase assays using increasing AdoHcy concentrations and proportionally decreasing AdoMet concentrations. The assay was performed in $30 \mu \mathrm{l}$ with AdoHcy at the indicated concentrations and total AdoHcy + AdoMet concentrations of $1 \mu \mathrm{M}(\diamond), 3 \mu \mathrm{M}$ $(\boldsymbol{\nabla}), 10 \mu \mathrm{M}(\mathbf{\Delta})$, and $30 \mu \mathrm{M}(\boldsymbol{\square})$. (A) The AdoHcy/AdoMet mixtures were combined with 20 $\mu \mathrm{l}$ antibody/tracer complex, and FP was measured $2 \mathrm{~h}$ postaddition. (B) Differential $\mathrm{mP}$ was determined by subtracting $\mathrm{mP}$ values at 0 AdoHcy from $\mathrm{mP}$ values at the indicated AdoHcy concentrations. 

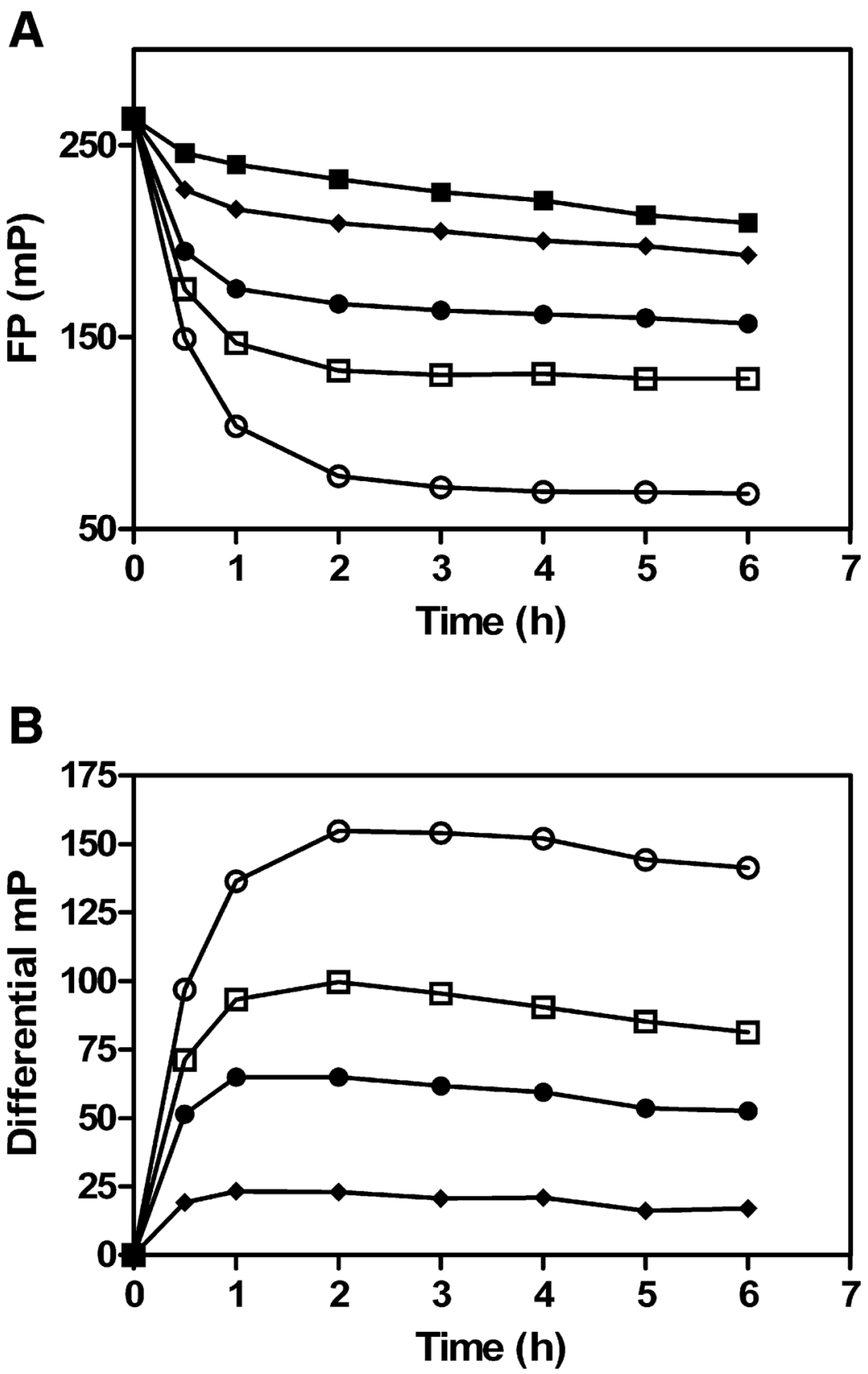

Fig. 4.

Time course of mock methyltransferase assays after the addition of antibody/tracer. Mock enzyme reactions were made using the indicated AdoHcy concentrations in a proportionally decreasing AdoMet background. Here $30 \mu \mathrm{l}$ of $0 \mathrm{nM}(\boldsymbol{\square}), 10 \mathrm{nM}(\boldsymbol{\square}), 40 \mathrm{nM}(\bullet), 80 \mathrm{nM}$ ( $\square$ ), or $320 \mathrm{nM}(\bigcirc)$ AdoHcy in $3 \mu \mathrm{M}$ total AdoHcy + AdoMet was added to $20 \mu \mathrm{l}$ antibody/ tracer complex. (A) Fluorescence polarization was measured at the indicated times after the addition of antibody/tracer. (B) Differential $\mathrm{mP}$ was determined by subtracting $\mathrm{mP}$ values at 0 AdoHcy from $\mathrm{mP}$ values at the indicated AdoHcy concentrations. 

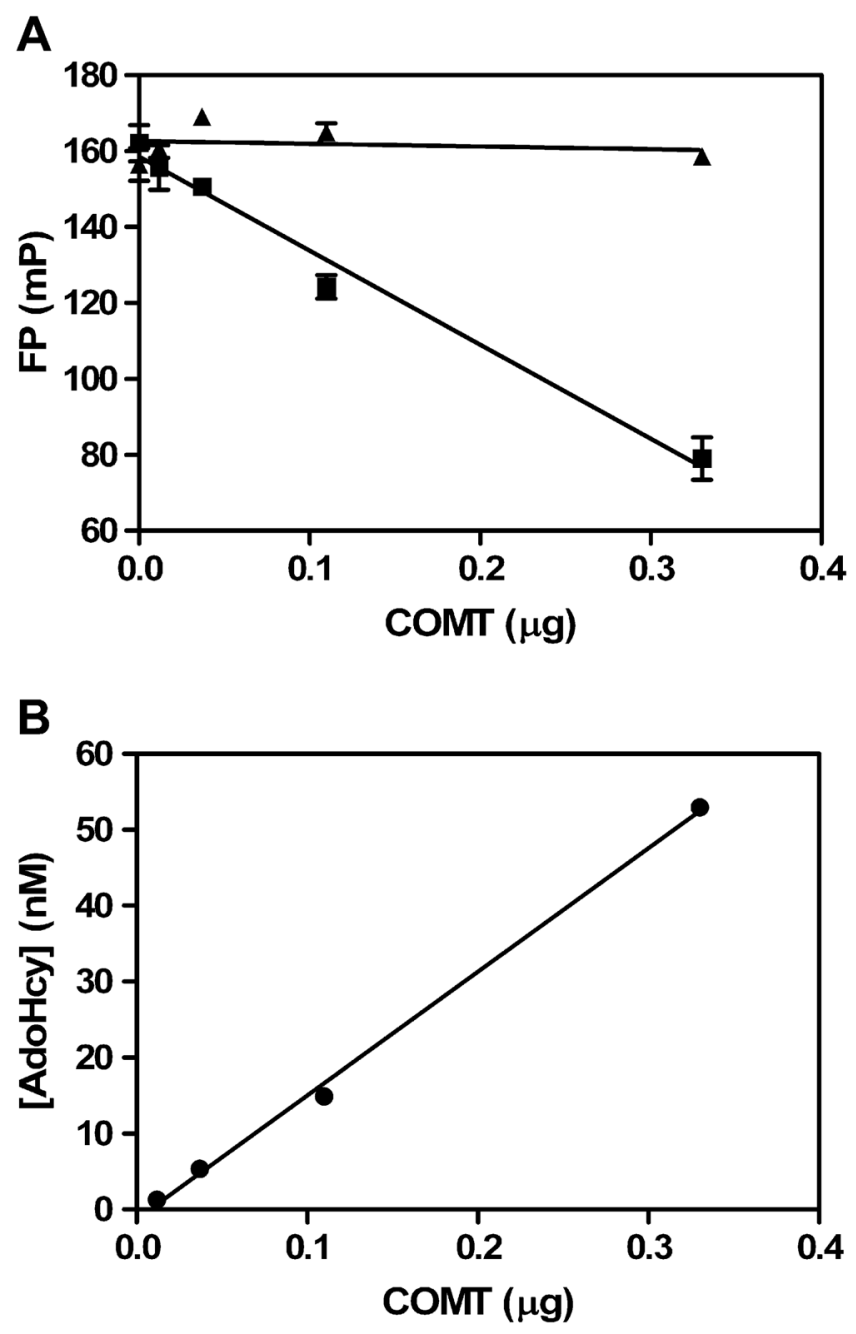

Fig. 5.

COMT enzyme activity determined by FP assay. (A) Catechol- $O$-methyltransferase reactions were performed using COMT enzyme at indicated amounts per reaction and $3 \mu \mathrm{M}$ AdoMet in the presence $(\boldsymbol{\square})$ or absence $(\boldsymbol{\Delta})$ of $250 \mu \mathrm{M}$ DBA substrate. The reaction volume and incubation time were $30 \mu \mathrm{l}$ and $10 \mathrm{~min}$, respectively. The reaction was initiated by the addition of AdoMet and was terminated with $10 \mathrm{mM}$ EDTA in the $20-\mu \mathrm{l}$ antibody/tracer complex solution. FP was measured $1 \mathrm{~h}$ after termination of the reaction. (B) Concentration of AdoHcy produced in panel A was calculated by comparing differential $\mathrm{mP}$ values with a standard AdoHcy curve. 


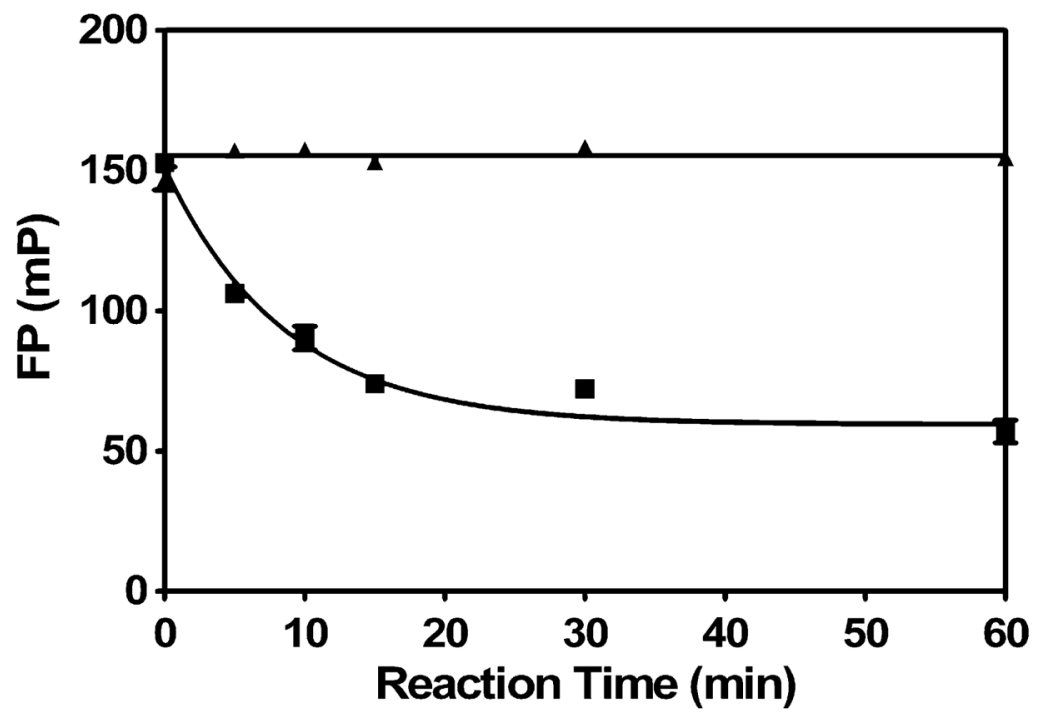

Fig. 6.

Time course of COMT activity assay. Reactions were performed for the indicated lengths of time using $0.33 \mu \mathrm{g}$ COMT enzyme and $3 \mu \mathrm{M}$ AdoMet in the presence $(\boldsymbol{\square})$ or absence $(\mathbf{\Delta})$ of $250 \mu \mathrm{M}$ DBA substrate. Reactions were initiated with the addition of AdoMet, and all reactions were terminated simultaneously with the addition of $10 \mathrm{mM}$ EDTA in the $20-\mu \mathrm{l}$ antibody/tracer complex solution. FP was measured $1 \mathrm{~h}$ after termination of the reaction. 


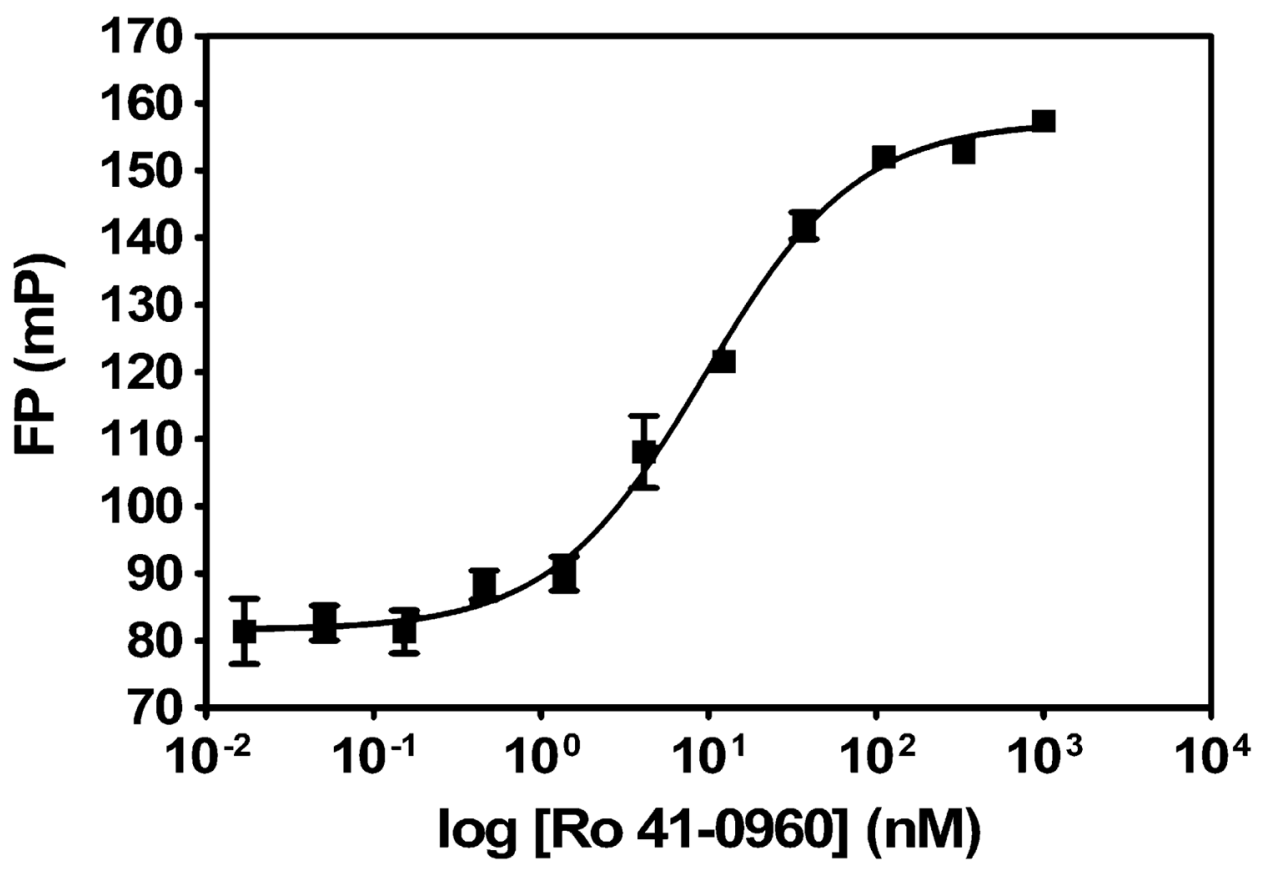

Fig. 7.

Inhibition curve using a known COMT inhibitor. Reactions were performed using $0.33 \mu \mathrm{g}$ COMT enzyme, $3 \mu \mathrm{M}$ AdoMet, and $250 \mu \mathrm{M}$ DBA substrate with indicated concentrations of Ro 41-0960 inhibitor. COMT and Ro 41-0960 were preincubated together for 5 min, and then the reactions were initiated by the addition of AdoMet. Reactions were terminated with $10 \mathrm{mM}$ EDTA in the 20- $\mu \mathrm{l}$ antibody/tracer complex solution. FP was determined $1 \mathrm{~h}$ after terminating the reaction. The average $\mathrm{IC}_{50}$ value from three independent experiments was $12 \mathrm{nM}$. 